\title{
Blending New-generation Warfare and Soft Power: Hybrid Dimensions of Russia-Bulgaria Relations
}

\section{Stefan Hadjitodorov and Martin Sokolov}

Center for National Security and Defense Research at the Bulgarian Academy of Sciences, http://www.cnsdr.bas.bg

\begin{abstract}
In order to effectively counter hybrid warfare, it is necessary to understand it. However, certain aspects of hybrid warfare are often confused with traditional soft power. This article aims to highlight the differences between the two by analyzing the relationship between Bulgaria and Russia. The latter enjoys considerable opportunities to exercise soft power, but often must accompany them with hybrid means. Yet, labeling everything as hybrid warfare becomes detrimental to the topic itself. Moreover, it runs the risk of ascribing greater power to the Kremlin which may not truly be the case. The aim of the authors is to expose the threats, opportunities, and limits of Russian influence in Bulgaria and the possible outcomes.
\end{abstract}

Keywords: Russia, Bulgaria, hybrid threats, hybrid warfare, soft power.

\section{Introduction}

Following Russia's illegal annexation of Crimea in 2014 the popularity of the term 'hybrid warfare' increased significantly. Albeit many scholars and strategists have addressed this topic since the 90 s, it has also become part of the lexicon of journalists, politicians, and the general public. In 2015 Janis Berzins correctly noted that "the word hybrid is catchy since it may represent a mix of anything." ${ }^{1}$ This often leads to mistaking soft power, or even mere interaction be-

1 Jānis Bērziṇš, “A New Generation of Warfare," Per Concordiam 6, no. 3 (2015): 24, accessed March 13, 2018, http://www.marshallcenter.org/mcpublicweb/MCDocs/ files/College/F_Publications/perConcordiam/pC_V6N3_en.pdf. 
tween states, for forms of hybrid warfare. The crux is that the term has come to serve as a general description of all non-conventional conflicts.

Nevertheless, research and debate regarding hybrid warfare are vital, as Russia's version - the new generation warfare-caught almost the entire world off-guard in 2014. Moreover, in many ways, the United States, NATO, and the European Union are still struggling to find an adequate defense or countermeasures against it. This is especially troubling, as non-linear warfare is nothing new. Even in recent years we have seen examples of hybrid warfare conducted by Hezbollah against Israel, Turkey against the Kurds, and even Russia against Georgia in 2008. Moreover, in Bulgaria's case the majority of risks for its national security emanate from outside its borders. ${ }^{2}$

This article focuses on the relations between Russia and Bulgaria. This case is particularly interesting as the countries share many ties - historic, cultural, linguistic, and economic, among many others. Thus, it is evident that the Kremlin has many opportunities to exercise influence in Bulgaria and even shape public perception and mold the political landscape. The authors will try to enhance the understanding of hybrid warfare and its ambit by analyzing the relations between a resurging power and a country that is both an EU and NATO member. To do so, the article first looks at what is de facto hybrid warfare, both from a historical and military perspective. Second, the authors analyze Russia's new generation warfare. Finally, the paper considers the concrete examples of Russia's hybrid warfare against Bulgaria.

\section{Hybrid Warfare}

Due to the popularity of the term, its definitions have grown exponentially in recent years. However, it is vital to have a working definition, as the way policyand decision-makers perceive it, determines their response. The authors offer two possible ways of analyzing this 'new' form of warfare - from a historical and a military/operational perspective.

Warfare sui generis is a socio-historical phenomenon and, as Daniel-Cornel Ştefănescu notes, is "a violent manifestation of conflicting political relations between large groups of people (classes, nations, states, coalitions of states), organized military groups" ${ }^{3}$ that pursue a specific goal - territorial, religious, political, economic, or other. Thus, it should be of no surprise that throughout his-

2 Ivo Zahariev, "Building up Capabilities for Assessment of Crisis and Conflict Regions in Response of Hybrid Threats and Conflicts," Bulgarian Military Thought, April 11, 2018, accessed September 15, 2018, https://bvm.bg/en/2018/04/11/\%D0\%B8\%D0\% B7\%D0\%B3\%D1\%80\%D0\%B0\%D0\%B6\%D0\%B4\%D0\%B0\%D0\%BD\%D0\%B5-\%D0\%BD \%D0\%B0-\%D1\%81\%D0\%BF\%D0\%BE\%D1\%81\%D0\%BE\%D0\%B1\%D0\%BD\%D0\%BE\%D1 \%81\%D1\%82\%D0\%B8-\%D0\%B7\%D0\%B0-

\%D0\%BE\%D1\%86\%D0\%B5\%D0\%BD\%D0\%BA\%D0\%B0-\%D0\%BD/.

3 Daniel-Cornel Ştefănescu, "Is hybrid Warfare a New Manner of Conducting Warfare," Review of the Air Force Academy 14, no. 2 (2016): 155-160, quote on p. 155, https://doi.org/10.19062/1842-9238.2016.14.2.20. 
tory, military strategists have strived to develop tactics to compel the enemy to do their bidding. The earliest definition of what is currently described as hybrid warfare, can probably be identified in the writing of the Chinese general, Sun Tzu. The ancient military strategist wrote about attacking the orthodox with the unorthodox ${ }^{4}$ as way to surprise the enemy, and emphasized that the supreme art of war is to subdue your enemy without fighting. ${ }^{5}$ However, to get a more concrete definition, one can turn to Peter Mansoor, a military historian, who describes it as a "conflict involving a combination of conventional military forces and irregulars (guerrillas, insurgents, and terrorists), which could include both state and non-state actors, aimed at achieving a common political purpose." ${ }^{6}$ This indicates, first, that since ancient times military strategists have considered ways to militarize various means and, second, that what we now refer to as "hybrid" is nothing particularly new. Moreover, using insurgents and guerilla fighters is also not only a $21^{\text {st }}$ century strategy. Such fighters have been used throughout history and have caused much trouble for many superior armies - from the US's wars in Vietnam to Iraq and Afghanistan. History is full of such examples, formidable armies like Hitler's Wermacht and Napoleon's Grand Armee also "struggled to combat irregular fighters who understood and exploited the local human and geographical terrain and targeted vulnerable logistic bases and lines of communication." 7

At the turn of the century, the definition expanded to incorporate non-state actors and cyberwarfare. Thus, elaborations on hybrid warfare were focused on blending conventional and irregular methods in conflict, or in other words: "Threats that incorporate a full range of different modes of warfare including conventional capabilities, irregular tactics and formations, terrorist acts including indiscriminate violence and coercion, and criminal disorder, conducted by both sides and a variety of non-state actors." ${ }^{8}$ It is de facto this blending of conventional and irregular means of waging war that distinguishes hybrid warfare from conventional historical forms. As Prof. James Wither emphasizes, in the past, "conventional and irregular operations tended to take place concurrently but separately, rather than being integrated." 9 Moreover, historically, irregular fighters were secondary to the conventional military campaign, where-

4 Sun Tzu, The Art of War, accessed April 27, 2018, http://classics.mit.edu/Tzu/ artwar.html.

5 Tzu, The Art of War.

6 Peter R. Mansoor, "Hybrid War in History," in Hybrid Warfare: Fighting Complex Opponents from the Ancient World to the Present, ed. Williamson Murray and Peter R. Mansoor (Cambridge: Cambridge University Press, 2012), 2.

7 James K. Wither, "Making Sense of Hybrid Warfare," Connections 15, no. 2 (2016): 73-87.

8 Frank G. Hoffman, Conflict in the $21^{\text {st }}$ Century: The Rise of Hybrid Wars (Arlington, VA: Potomac Institute for Policy Studies, December 2007), 8.

9 Wither, "Making Sense of Hybrid Warfare." 
as now they have come to take place concurrently and in an integrated manner.

Furthermore, a significant aspect of contemporary conflicts are the developments in information warfare. This particular issue came into the spotlight during the events that unfolded in Crimea in 2014 and afterwards. Moscow employed methods that blended conventional and irregular combat, economic coercion, sponsorship of political protests, and the now notorious disinformation campaign. This led the then NATO Secretary General Anders Fogh Rasmusen to define hybrid warfare as a "combination of military action, covert operations and an aggressive program of disinformation." 10 Interestingly, while from a historical perspective hybrid warfare is nothing new, this definition emphasizes the non-military means and the importance of information warfare. This de facto shows the horizontal growth of warfare: employing all possible means, including conventional interaction between states, to blur the lines not only between war and peace, but between competition and subversion.

The Prussian General Carl Philip von Clausewitz once famously described war as "the continuation of politics by other means." 11 However, politics and warfare are not divided by a single 'step.' Hybrid warfare aims to incorporate the entire spectrum between the two - if the means to achieving the political goal has a "Clausewitzian" method of achieving it, i.e. to give the unconventional a conventional military aim, the hybrid aspect is added. This itself places greater emphasis on the non-conventional means to conduct such operations. $^{12}$

\section{Not Only Russia}

While this paper focuses on Russia, it must be emphasized that Kremlin is neither the creator of hybrid warfare, nor the sole actor practicing it. With its supremacy after the end of the Cold War, the West has forced other state and non-state actors to develop strategies and tactics than can act as a countermeasure. As they seek to exploit vulnerabilities, they are asymmetric and can therefore shift into non-military fields, further expanding the grey area between war and peace. ${ }^{13}$

10 Mark Landler and Michael R. Gordon, "NATO Chief Warns of Duplicity by Putin on Ukraine," The New York Times, July 8, 2014, accessed March 16, 2018, http://www.nytimes.com/2014/07/09/world/europe/nato-chief-warns-of-duplicityby-putin-on-ukraine.html.

11 Carl von Clausewitz, On War, accessed April 16, 2018, https://www.clausewitz.com/ readings/OnWar1873/BK1ch01.html\#a.

12 See also Ivo Zahariev, "Assessment of Crisis and Conflict Regions in Response of Hybrid Threats and Conflicts," International Journal of Advanced Research, http://www.journalijar.com/articles-in-process/ (to be published).

13 Wither, "Making Sense of Hybrid Warfare." 
Additionally, many of the characteristics of 'hybrid warfare' are also part of the "fourth generation warfare," a contesting theory from the 1990s. ${ }^{14}$ A key concept of this was the importance of utilizing developing information technology, which made it possible to erode a state's will to engage in conflict by targeting decision-makers and the public via the internet. In this manner, it became possible to expand the definition warfare to include "cultural, social, legal, psychological and more dimensions where military power is less relevant." ${ }^{15}$

It is also to be noted that both 'fourth generation' and 'hybrid' warfare are very similar to the Chinese concept of 'unrestricted warfare.' 16 This argues for the need to utilize both military and non-military means to strike back. This, of course, means that unrestricted warfare incorporates computer hacking, financial warfare, terrorism, media disinformation, and even urban warfare. The authors argue that as a result of globalization, the nature of war itself has changed, moving beyond the military realm, where more means can be incorporated in a Clausewitzian manner. However, as Qiao Liang has eloquently stated: "the first rule of unrestricted warfare is that there are no rules with nothing forbidden." 17

Turkey is also striving to exercise, and to no small extent successfully, greater influence in the Balkans. This is predominantly done by strengthening its role among ethnic Turkish and Muslim minorities throughout the region. In Bulgaria, particularly, both groups were mobilized during the last parliamentary elections to support pro-Turkish parties in the country, namely the Movement for Rights and Freedoms and the newly formed DOST.

However, prior to Russia's invasion of Ukraine, the most cited example of hybrid warfare was the campaign carried out by Hezbollah in 2006. Considered a hybrid organization itself, ${ }^{18}$ Hezbollah managed to surprise Israel with its sophisticated blend of guerilla and military tactics and weaponry and communication systems matching the capabilities of developed states. ${ }^{19}$ Particular attention should be paid to the fact that, at strategic level, Hezbollah utilized the internet and media very efficiently for information and propaganda purposes. It was evident from the onset of the conflict that Hezbollah was able to influence people's opinion regarding the situation more effectively.

14 Tim Benbow, "Talking 'Bout Our Generation? Assessing the Concept of FourthGeneration Warfare," Comparative Strategy 27, no. 2 (2008): 148-163.

15 Wither, "Making Sense of Hybrid Warfare."

16 This concept was introduced in 1999 by Qiao Ling and Wang Xiangsui, Colonels from the People's Liberation Army.

17 Qiao Liang and Wang Xiangsui, Unrestricted Warfare (Beijing: PLA Literature and Arts Publishing House, 1999), 2, accessed March 17, 2018, https://www.oodaloop.com/ documents/unrestricted.pdf.

18 Eitan Azani, "The Hybrid Terrorist Organization: Hezbollah as a Case Study," Studies in Conflict \& Terrorism 36, no. 11 (2013), 899-916.

19 Wither, "Making Sense of Hybrid Warfare." 
Thus, non-linear or hybrid means of waging war are not limited to a specific state, and they are also not limited to state actors. However, as stated earlier, this paper focuses on Russia's understanding and conduct of such type of operations.

\section{New Generation Warfare}

It must be stressed that the term 'hybrid warfare' is a Western concept, whereas Russia refers to 'new generation warfare.' It is vital to highlight two key issues in this context. First, the Russian concept was introduced to understand Western 'influence' in the world. While the Chinese concept of 'unrestricted warfare' was aimed at identifying ways to counter the West's overwhelming hard and soft power through asymmetric means, the Russians, on the other hand, are convinced that since the collapse of the Soviet Union, the West has been waging a war against Russia. The tools used have been liberalism, international institutions, non-governmental organizations, and strategic communication. ${ }^{20}$

Second, understanding Russia's 'hybrid warfare' often comes from the wrongly labelled "Gerasimov Doctrine." This so-called doctrine is in fact a short paper written by the Chief of the General Staff of the Russian Federation, General Valery Gerasimov. The paper de facto delves into the first point - understanding the West's 'hybrid warfare.' It is clear that the Russian General argues the 'Colored Revolutions' and 'The Arab Spring' were a product of a 'new generation warfare.' Gerasimov thus proposes that "the focus of applied methods of conflict has altered in the direction of the broad use of political, economic, informational, humanitarian, and other non-military measure - applied in coordination with the protest potential of the population." 21

Therefore, from the Kremlin's point of view, they are merely catching up with what the Western powers and organizations have been doing for decades. They apparently regard their own disinformation campaigns and other operations as a counter-tool to the liberal democratic order. However, while the West seeks to promote democratic liberal values, Russia actively engages in activities it deems suitable - militarizing non-military means, blurring the lines between war and peace and between falsehood, truth, and reality. Perhaps it was Peter Pomerantsev who said it best: "The new Russia doesn't just deal with the petty disinformation, forgeries, lies, leaks, and cyber-sabotage usually associated with information warfare. It reinvents reality." 22

20 Mark Galeotti, "The 'Gerasimov Doctrine' and Russian Non-Linear War," In Moscow's Shadows, accessed May 1, 2018, https://inmoscowsshadows.wordpress.com/2014/ 07/06/the-gerasimov-doctrine-and-russian-non-linear-war/.

21 Galeotti, "The 'Gerasimov Doctrine' and Russian Non-Linear War."

22 Peter Pomerantsev, "How Russia Is Revolutionizing Information Warfare," Defense One, September 9, 2014, accessed March 7, 2018, http://www.defenseone.com/ threats/2014/09/how-russia-revolutionizing-information-warfare/93635. 
The most notable use of the 'new generation warfare,' of course, has been Russia's 2014 campaign in Ukraine, where it demonstrated a sophisticated blend of strategic communication, disinformation, cyber-attacks, covert troops, and psychological warfare. While a similar blend was also present during Moscow's endeavor in its 2008 invasion of Georgia, the campaign in Ukraine clearly shows Kremlin's understanding of what the wars of the future will look like. As Jānis Bērzinš notes, the success of Russia in Ukraine can be measured by the mere fact that, within three weeks and with only minor skirmishes, the moral of the Ukrainian army was crushed, and its 190 military bases surrendered. ${ }^{23,24}$

Once the "little green men" were deployed to Eastern Ukraine, they proceeded to block Ukrainian troops in their own bases. Afterwards, Russians began the second phase of their operation which consisted in psychological warfare, bribery, intimidation, and propaganda to undermine any form of resistance. This allowed them to achieve their objective without firing a shot. This led to a clean military victory on the battlefield, based on sophisticated use of strategic communication and simultaneously blending political, psychological, and information strategies. ${ }^{25}$ This type of waging war is perhaps best described by Jānis Bērzinšs, who usefully illustrates the shift from 'traditional' to hybrid warfare as transition:

- from direct destruction to direct influence

- from direct annihilation of the opponent to its inner decay

- from a war with weapons and technology to a culture war

- from a war with conventional forces to specially prepared forces and commercial irregular groupings

- from the traditional battleground to information/psychological warfare and war of perceptions

- from direct clash to contactless war

- from a superficial and compartmented war to a total war, including the enemy's internal side and base

- from war in the physical environment to a war in the human consciousness and in cyberspace

23 Jānis Bērzinšs, "Russia's New Generation Warfare in Ukraine: Implications for Latvian Defense Policy," Policy Paper no. 2 (National Defence Academy of Latvia, April 2014).

24 While Russia's annexation of Crimea and support of separatists in Eastern Ukraine has faced many difficulties since, to the point of their success being questioned today, at the time they were very efficient on both the strategic and tactical level. Since 2014 the Ukrainian military has also been able to improve to the point of countering separatists supported by the Russian military. For further information on this see Mykola Bieliskov, "Ukraine's Military Is Back," The National Interest, February 27, 2018, accessed May 2, 2018, http://nationalinterest.org/blog/thebuzz/ukraines-military-back-24674.

25 Tim Ripley and Bruce Jones, "Analysis: How Russia Annexed Crimea," IHS Jane's Defense Weekly 51, no. 14 (April 2014): 5. 
- from symmetric to asymmetric warfare by a combination of political, economic, information, technological, and ecological campaigns

- from war in a defined period of time to a state of permanent war as the natural condition in national life. ${ }^{26}$

Thus, it becomes clear why Russians place immense importance on information and psychological warfare - simply because they consider the mind to be the main battle space of the $21^{\text {st }}$ century. Not adding much to warfare from a historical perspective, ideally means defeating the adversary mentally before any direct engagement. Of course, this approach is not only limited to the enemy's troops but to the population as a whole. Berzins puts it bluntly: "the main objective is to reduce the necessity of deploying hard military power to the minimum necessary, making the opponent's military and civil population support the attacker to the detriment of their own government and country." 27 Thus, Russia's approach to current warfare is subversion of the enemy or, to use Clausewitz, compelling the enemy to do its bidding, but before the actual engagement or initiation of military operations.

Further insight on how Russia views contemporary wars is provided by Col. S.G. Chekinov and Lt. Gen. S.A. Bogdanov in their 2013 article "The Nature and Content of a New-Generation War." Like Gerasimov, they draw lessons from how the West, particularly the US, have conducted their military campaigns. The Russian authors identify eight particular steps of new-generation warfare:

1. Non-military measures that blend moral, information, psychological, ideological, and economic measures that aim at establishing a more favorable political, economic, and military environment.

2. Media, diplomatic channels, and top government and military agencies carry out coordinated special operations so as to mislead political and military leaders. This can include leaking false data, orders, directives, and instructions.

3. Bribing, deceiving, and/or intimidating government and military officers, to force them to abandon their duties.

4. Fuel discontent among the population. This can be further enhanced by the arrival of Russian 'volunteers.'

5. No-fly zones and blockades are established over the targeted country. Cooperation between private military contractors and armed opposition.

6. Large-scale reconnaissance and subversion operations are initiated and are immediately followed up upon with military action.

26 Bērziņš, "Russia's New Generation Warfare in Ukraine."

27 Bērziṇš, "Russia's New Generation Warfare in Ukraine." 
7. A combination of information, electronic warfare, and air force operations are launched. They are complimented with high-precision weapons.

8. The last points of resistance are eliminated through reconnaissance operations, special operations, and artillery and missile bombardment. $^{28}$

To sum up, again referring to Jānis Bērziņš: "Russians have placed the idea of influence at the very centre of their operational planning and used all possible levers to achieve this: skillful internal communications; deception operations; psychological operations and well-constructed external communications." 29 This allowed Russian operations to, paradoxically, be simultaneously evident while under the radar. By blurring the lines between war and peace, falsehood and reality, and inter-state relations and subversion, they are able to conduct hybrid war campaigns against many actors and the de facto manifestation of military operations becomes clear much later in time. The goal is to keep it clandestine until the last stage of the planned conflict. To turn to Sun Tzu, if one cannot defeat their enemy without fighting, they should at least try to "keep them in the dark" for as long as possible.

\section{Russia and Bulgaria}

To properly understand Russia's influence in Bulgaria, it is vital to stress that hybrid warfare is a not a goal, but a means of achieving it. Like war itself in Clausewitz's understanding, new-generation warfare is a means to achieve one's aims, thus it can be both a continuation of politics and a contribution to it, simultaneously. Therefore, to understand Russian influence and hybrid war against Bulgaria specifically, and the West in general, it is vital to first identify and understand Moscow's de facto goal.

The Kremlin stated in its National Security Strategy that it considers NATO's enlargement a threat to national security. ${ }^{30}$ This is also valid to a lesser extent for the European Union, but this may very well change if the EU enhances its common defense and security, particularly if an 'EU army' is created. Therefore, one of Moscow's key interests is to prevent and counter both the EU and NATO enlargements. This consists of two layers. One involves creating a periphery of instability along Russia's borders and strengthening Moscow's say in

28 Taken from Bērzinš, "Russia's New Generation Warfare in Ukraine," based on the work of Col. S.G. Chekinov and Lt. Gen. S.A. Bogdanov, "The Nature and Content of a New-Generation War," Military Thought, accessed April 16, 2018, http://www.eastviewpress.com/Files/MT_FROM\%20THE\%20CURRENT\%20ISSUE_No .4_2013.pdf.

29 Bērziňš, "Russia's New Generation Warfare in Ukraine."

30 "Russian National Security Strategy 2015-2020," accessed May 2, 2018, http://www.ieee.es/Galerias/fichero/OtrasPublicaciones/Internacional/2016/Russia n-National-Security-Strategy-31Dec2015.pdf. 
countries that are not members of both organizations yet. The second challenges the EU and NATO unity and decision-making by preoccupying members with other issues, in this manner pulling attention away from the enlargement processes.

Bulgaria is in the second group, as it is a member of both Western organizations. However, it is evident that the Kremlin is using its influence in the country, enhancing it with hybrid means to place the cohesion and future of the organizations under question. It is important to note that there is no need for these ideas to have any substance, rather the aim is to place them in the minds of Bulgarian citizens. This, of course, is achieved through spreading fake news, misinformation, and direct propaganda. ${ }^{31}$ However, before elaborating further, the deep-rooted pro-Russian mentality among Bulgarians must be noted.

It is a telling story that, according to a public opinion poll by Alpha Research from 2015, over half of the inquired people, $54.3 \%$, continued to hold positive views of Russia, despite the annexation of Crimea. Moreover, another $6.3 \%$ changed their perception to "more favorable." However, nearly $30 \%$ came to view the Kremlin in a more negative light. This, of course, has also impacted people's view on the sanctions placed by the EU on Moscow. While nearly $40 \%$ approved further sanctions if the ceasefire agreement was violated by Russia, $60 \%$ either opposed or strongly opposed such measures. ${ }^{32}$ This led to a peculiar situation during Bulgaria's presidential elections in 2017, where all major candidates and parties spoke in favor of lifting the sanctions. ${ }^{33}$ However, while there were certain misinformation campaigns and fake news regarding the issue, this is hardly the case of hybrid warfare, which Russia does not really need to wage. Certainly, the Kremlin used hybrid means to influence the public perceptions and sentiments, but this situation was rather the case of exerting traditional soft power.

Furthermore, there are clear limits to Russian influence and hybrid efforts. The same research agency asked its participants how they would vote in a hypothetical referendum on Bulgaria remaining in the EU and NATO or aligning with Russia and the Eurasian Union. Over $62.8 \%$ were in favor of the country remaining in the Western organizations. ${ }^{34}$ Moscow does not have the economic

31 According to Reporters without Borders, Bulgaria is now the lowest ranking country in the EU regarding media freedom. In their 2018 report Bulgaria has dropped to $111^{\text {th }}$ position, which is also the lower than the candidate-EU states from the Western Balkans. The report is available at https://rsf.org/en/bulgaria (accessed May 1, 2018).

32 Alpha Research, "Bulgarian Foreign Policy, the Russia-Ukraine conflict, and National Security," accessed March 7, 2018, http://alpharesearch.bg/userfiles/file/0215_ Public_Opinion_AR_present.pdf.

33 Yordan Bozhilov, "The Role of Russia on the Balkans" (speech at the international conference "Balkan Networks and Stability - Connecting Co-operative and Human Security," Rome, 6-7 April 2017). A transcript of the speech is available at http://sofiaforum.bg/front/rtf.php?cid=8\&sid=58 (accessed April 4, 2018).

34 Alpha Research, "Bulgarian Foreign Policy." 
and political capabilities to serve as an alternative to the West; even among its supporters throughout Europe. Moreover, albeit Bulgaria continues to be the poorest and most corrupt member in the European Union and remains outside the Eurozone and Schengen, it is in Western states that people find 'role models.' The Kremlin is well aware of this fact and, simply because it is weaker, it resorts to the use of hybrid warfare.

It cannot be overemphasized that there needs to be a distinction between hybrid warfare and soft power. First, by branding every type of influence as hybrid warfare, one also risks confusing them with normal inter-state relations and competition. Second, by ascribing to Russia the power to influence everything everywhere, one plays into the Kremlin's hands.

Russian influence is particularly noticeable in Bulgaria's economy. Its exercise is conducted via strategic investments, the housing market, but especially via the energy sector. Bulgaria is almost completely dependent on importing Russian oil and gas. This has created a political and business lobby that can push for specific energy projects that disproportionately favor Russia. This was evident in the South Stream pipeline projects which is still unclear how much it would have cost Bulgaria. ${ }^{35}$ Moreover, the country was going to fund its part of the pipeline via a loan from Gazprom with an interest that could have made the gas price the highest in the EU. It also remains unclear how much Bulgaria has invested in the pipeline before it fell apart, and how much more would have been required for the successful completion. ${ }^{36}$

Furthermore, Bulgaria's only nuclear power plant, NPP Kozloduy, is also completely dependent on Russian fuel. What is more, Russia is responsible for the entire life cycle of the nuclear fuel: from delivering it to returning and disposing of the used nuclear fuel. It is to be noted that there are still advocates for building a second NPP in Belene - a project wrapped in controversy. This specific project dates back to the 1980s but gained popularity again during the second term of President Georgi Parvanov in the late 2000s. It was discontinued again in 2013, but has now resurfaced. Like the South Stream pipeline, it will again favor Russian over Bulgarian economic interests. Several studies from think-tanks, non-governmental organizations, and the Bulgarian Academy of Sciences have emphasized that the project could be sustainable only if it meets specific criteria - foreign investor, minority part for the state, low interest on the loan, etc. However, those are almost impossible to meet. ${ }^{37,38}$

35 For more information regarding the South Stream project see: Centre for the Study of Democracy, "Transparent Governance for Greater Energy Security in CEE," Policy Brief no. 58 (September 2015), accessed April 3, 2018, http://www.csd.bg/ igardev/ typo3/artShow.php?id=17515.

36 “'Gazprom,' how we miss you," Capital, June 9, 2017 (“'Gazprom,' kak ni lipsvash”) accessed April 27, 2018, https://www.capital.bg/politika_i_ikonomika/bulgaria/ 2017/06/09/2985663_gazprom_kolko_ni_lipsvash/.

37 For detailed information on NPP Belene see: Iliyan Vasilev, "The Belene NPP Project - Mission Impossible?" (Centre for Balkan and Black Sea Studies, February 2012); and 
Interestingly, both projects were supported by pro-Russian media outlets in Bulgaria. These outlets advocated for these projects, claiming that they would create jobs, and ultimately the EU was blamed for their failures. This provides an example of 'traditional influence' enhanced by misinformation and fake news campaigns which are, of course, elements of hybrid warfare.

The situation is similar in the defense sector. Bulgaria committed to improving its military before it became a NATO member in 2004. However, there have been few and rare improvements, and very few cases of procuring new capabilities. Bulgaria still heavily relies on its Soviet-era weaponry. This is particularly problematic for the air force. There have been many discussions regarding acquiring new fighter jets. In a bid in 2016-2017, the government chose to acquire Grippens from Sweden, while the offer of second-hand F-16s from Portugal was the not evaluated on the basis of formal reasons. However, due to suspicions that lobbyist had promoted an offer that was not in Bulgaria's interests, the entire procedure fell apart and it remains unclear when the country will acquire new fighter jets for its air force. ${ }^{39}$ Inter alia, the current government agreed to send its current MiG-29s for repairs to RSK MiG. It is unclear how much the actual cost of repairs and price per flying hour will amount to, but many experts consider it to be close to that of procuring new planes. ${ }^{40}$

It is also interesting to note the massive misinformation regarding the price of the Grippens and F-16. Specific media outlets strived to convince people that it would be a mistake to procure a new type of fighter plane, especially secondhand USA-made. Thus, once again Russia achieved a deal that disproportionately promoted its own interests over those of Bulgaria. This, of course, was strongly promoted by the pro-Russian parties in Bulgaria, currently also in a coalition government with GERB. Particularly, the nationalist party of Ataka has always favored Moscow, and is vocally EU- and NATO- sceptic. However, there is also another aspect to this combination of soft power and hybrid means. Due to Bulgaria's poor military capabilities, it cannot properly fulfil its NATO obligations. An interesting aspect has been placed forward by Mikhail Naydenov, who

the Centre for the Study of Democracy's 2014 annual report, available at http://www.csd.bg/artShow.php?id=17243 (accessed March 30, 2018).

38 The Bulgarian's Academy of Sciences' report, albeit surrounded with controversy, still concluded that it is highly unlikely that NPP would be completed as a sustainable project. The reports is available at http://www.bas.bg/IR2.pdf (accessed April 16, 2018).

39 See Todor Tagarev, "Lessons from the Procedure of Acquiring a New Type of Combat Aircraft, 1999-2017," IT4Sec Reports no. 131 (Sofia: Institute of ICT, May 2018), accessed May 2, 2018, https://it4sec.org/article/lessons-procedure-acquiring-newtype-combat-aircraft-1999-2017.

40 "The Atlantic Council Has Seen Unprofitable Clauses in the Order for Russia to Repair the MiGs ("Atlanticheskiyat suvet vidya neizgodni klauzi v poruchkata kum Rosiya za remont na MiG-ovete)" Dnevnik, March 15, 2018, accessed March 21, 2018, https://www.dnevnik.bg/bulgaria/2018/03/15/3147311_atlanticheskiiat_suvet_pred upredi_za_neizgodni_klauzi/. 
suggested that these hybrid means also have the aim of creating the adversary you want. ${ }^{41}$ To elaborate, by having something similar to a monopoly over Bulgaria's armed forces, Moscow can de facto dictate the capabilities and equipment Bulgaria procures for its defense.

A more evident manifestation of hybrid means, however, were the cyberattacks on the day of national referendum and local elections in 2015. Russian hackers carried out cyber-attacks against the Presidency, the Central Electoral Committee, and the Council of Ministers, among others. ${ }^{42}$ The then President, Rosen Plevneliev, who was overtly pro-EU and pro-NATO, and also frequently and openly criticized Russia, even remarked once that "Moscow does not see partners, but vassals." 43 Needless to say, the Kremlin did not take kindly to President Plevneliev, and pro-Russian media was frequently spreading fake news regarding his presidency.

As stated, fake news, disinformation, and general strategic communications are easy for Russia to conduct in Bulgaria. They find fertile ground in the country and resonate with the many pro-Russian citizens in the country. It begins to pose a threat, however, when they become of Clausewitzian nature. This, perhaps, is the case of the Bulgarian National Union "Shipka" (BNO Shipka). ${ }^{44}$ This is a group which formed at the wake of the migration crisis that supposedly self-organized to protect the country's Southern border. They are led by a former non-commissioned officer with a shady past and search the forests and mountains for immigrants, whom they then apprehend. While they are supposedly not doing anything illegal, it is the manner in which they self-organize, promote, and carry out their exercises. ${ }^{45}$ They have also stated that they consider NATO and the EU occupiers that need to be expelled from Bulgaria. Moreover, at one point they also promoted on their website the opportunity for anyone interested to apply for training abroad, most likely in Russia or another ex-Soviet country. ${ }^{46}$ While their sources of funding remain unclear and it

41 Mikhail Naydenov, "The subversion of the Bulgarian defence system - the Russian way," Defense \& Security Analysis 34, no. 1 (February 2018): 93-112, accessed May 2, 2018, https://www.tandfonline.com/doi/full/10.1080/14751798.2018.1421408.

42 Interview of President Plevneliev for the BBC, November 4, 2016, accessed April 17, 2018, https://www.president.bg/news3428/interview-of-president-plevneliev-forthe-bbc.html\&lang=en.

43 Interview of President Plevneliev for the Frankfurter Allgemeine Zeitung, October 4, 2014, accessed April 30, 2018, http://www.rosenplevneliev.bg/7/54/news item.html.

44 Homepage of the Bulgarian Military Union "Shipka," https://www.bnoshipka.org/ en/.

45 See also Mac Bishop, "Bulgarian Vigilantes Patrol Turkey Border to Keep Migrants Out," NBC News, March 10, 2017, accessed April 19, 2018, https://www.nbcnews.com/storyline/europes-border-crisis/bulgarian-vigilantespatrol-turkey-border-keep-migrants-out-n723481.

46 "A pro-Russian coup is looming in Bulgaria, the Russian embassy is silent (Zree rubladzhiiski prevrat $\vee$ Bulgariya, ruskoto posolstvo mulchi)," Faktor.bg, April 20, 
would not be just to immediately claim for Russia's direct sponsoring of BNO Shipka, it is at the very least a by-product of Russian propaganda and disinformation.

Thus, the blend of soft power, information warfare, and specific manifestations of hybrid means is evident in Bulgaria. Russia is, for the time being, keeping and enhancing its direct influence in the country. It is to be emphasized that a key 'ally' of Kremlin's influence in Bulgaria has been the Bulgarian Orthodox church, which very frequently echo their 'colleagues' from Russia's Orthodox Church. ${ }^{47}$ This is particularly important in the context of the Russian Church serving as more of an extension than a tool of Kremlin politics. Thus, their Bulgarian counterparts have a direct role in Russian soft power and hybrid endeavors. This was particularly evident in a visit of the Patriarch Kirill to Bulgaria for the country's national holiday March 3, which celebrates the liberation from Ottoman rule. Of particular interest is the fact that the Patriarch had a meeting with President Radev. During their meeting Patriarch Kirill criticized Bulgaria's president primarily on the issue that he had acknowledged the role of Finns, Romanians and Ukrainians in the liberation war of 1877-78 and has expressed his gratitude to others than Russia. A second round of criticism from the Russian Patriarch came in an interview for Bulgarian media, right before his departure flight. ${ }^{48}$ Russian media continued their bombardments of critiques labelling President Radev as a "puppet of the West." 49

A plausible reason for these sudden criticisms of the Kremlin-favored President is the fact that Bulgaria declared the integration of the countries from the Western Balkans as a priority for its Presidency of the Council of the European Union. ${ }^{50}$ This is clearly at odds with Russia's aspirations for the Balkan region. This highlights the fact that Moscow may have far more influence that eludes the eye. Moreover, it also highlights the fact that Russia may be seeking to enhance its 'say' in Bulgarian affairs. Bearing in mind that Russia has most probably achieved maximum influence via its soft power in the country, this possibly

2016, accessed May 1, 2018, https://www.faktor.bg/bg/articles/petak-13/-zreerubladzhiyski-prevrat-v-balgariya-ruskoto-posolstvo-malchi-72016.

47 Atanas Slavov, "The Bulgarian Orthodox Church - An Instrument for Russian Influence in the Region?" Bulgaria Analytica, June 28, 2017, accessed April 29, 2018, http://bulgariaanalytica.org/en/2017/06/28/the-bulgarian-orthodox-church/.

48 "Russian Patriarch unhappy at Bulgarian view of Russia's 1877-1878 war role," Reuters, March 6, 2018, accessed March 9, 2018, www.reuters.com/article/usbulgaria-russia-patriarch/russian-patriarch-unhappy-at-bulgarian-view-of-russias1877-1878-war-role-idUSKBN1GG144.

49 "Russian Priests: Radev is a Cowardly Puppet of the West in a Third-rate Country (Ruski sveshtenici: Radev e strahliva marionetka na Zapada v tretorazredna strana)," Dnevnik, March 9, 2018, accessed March 10, 2018, https://www.dnevnik.bg/bulgaria/2018/03/09/3143033_ruski_sveshtenici_radev_e_ strahliva_marionetka_na/.

50 See the official website of Bulgaria's Presidency of the Council of the EU at https://eu2018bg.bg/en/28. 
indicates that it may resort to more clandestine and hybrid means to exercise power.

\section{Conclusion}

It is clear that Russia is engaged in a state of permanent hybrid war with the West. This is how Moscow has come to conduct $21^{\text {st }}$ century international relations. The Kremlin utilizes a large plethora of peaceful tools and means in a Clausewitzian manner - from economics and energy, to religion and information. Democracies are particularly vulnerable to such influence due to liberties and means of mass information. Thus, Russia is striking at the very heart of democracies - the demos. It is striving to influence and shape people's perceptions. However, to properly understand and ultimately counter the Kremlin, one must not mistake normal inter-state relations and soft power for newgeneration warfare, as this again plays into Moscow's favor.

The situation remains problematic in Bulgaria where, due to its traditional influence and soft power, Russia can easily enhance its impact by adding hybrid means. This does not only impede the Bulgarian state itself, but may, as the Kremlin strives, lead to challenging the unity of the EU and NATO. Towards this purpose, after all, Russia is using hybrid means in more than one country, and possibly in the majority, if not all, members and candidates for membership in both organizations.

The answer to these new threats is twofold. First, countries need to acknowledge the dangers of Russian influence. Further efforts in improving the quality of education can decrease people's susceptibility to fake news, disinformation operations, and propaganda. This has proven very effective, as demonstrated in the case of Finland. ${ }^{51}$ Second, new-generation warfare must be matched with more cooperation and unity among NATO, the EU, and the candidate-states. Steps have been taken in this direction, such as STRATCom, but more efforts are necessary. The rather simple antidote to new generation warfare is strengthening democracy, the rule of law, and unity. However, the main target needs to be the fight against corruption, as this is the vulnerability the enables adversaries to employ hybrid means in order to bend the other to their own will.

51 Reid Standish, "Why Is Finland Able to Fend Off Putin's Information War?" Foreign Policy, March 1, 2017, accessed April 29, 2018, http://foreignpolicy.com/2017/03/ 01/why-is-finland-able-to-fend-off-putins-information-war/. 


\section{About the Authors}

Prof. Stefan Hadjitodorov is the director of the Center for National Security and Defense Research at the Bulgarian Academy of Sciences. He graduated from Technical University of Sofia, Faculty of Automation and from the Institute of Applied Mathematics of the same university. His research interests and activities are in the field of Pattern Recognition, Data Analysis, Machine Learning, Decision Support System and also in the field of Security and Defense, in particular in risk assessment and protection of critical infrastructure, crisis management, hybrid warfare. He has more than 25 publications on national security and defense issues. In 1994-2015 he was the national representative to the NATO Science Committee. In 2007-2009 he was a member of the European Security Research and Innovation Forum and in 2006-20013 - member of the "Security" Program Committee of the Seventh Framework Program of the European Union.E-mail: sthadj@bas.bg.

Martin Sokolov is an expert at the Center for National Security and Defense Research at the Bulgarian Academy of Sciences and a researcher at Sofia Security Forum. His research focuses on hybrid threats, EU and NATO security, Russia, the Balkans and the Black Sea region, and North Korea. He has produced several articles and papers on these topics, as well as participated in many lectures and roundtables. Mr. Sokolov holds a MA in International Relations and International Organizations from the University of Groningen, the Netherlands, and a BA in Politics and International Relations from the University of Hull, the United Kingdom. E-mail: martinsokolov@abv.bg. 